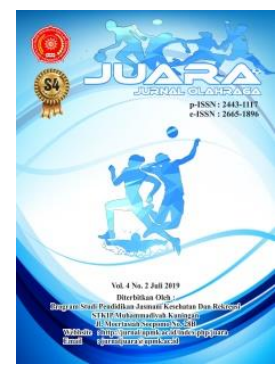

\title{
Kejadian Cedera Pada Pemain Sepak Takraw
}

\section{Sepaktakraw Players Injuries Event}

\author{
Astry Khairunnisa ${ }^{1)}$, Pipit Pitriani ${ }^{2)}$ \\ 1,2 Faculty of Physical Education and Health, Universitas Pendidikan Indonesia, Jl. DR. Setiabudi \\ No.229, Isola, Kec. Sukasari, Kota Bandung, Jawa Barat 40154, Indonesia \\ email: $\underline{\text { astrykhairunnisa5@upi.edu }}^{1}{ }^{\text {, pipitpitriyani@upi.edu }}{ }^{2}$
}

\section{Info Artikel}

Sejarah Artikel:

Diterima 27 Juni 2019

Disetujui 09 September 2019

Dipublikasikan 26 September 2019

Keywords:

Injury, sepaktakraw, players, acrobatic

\begin{abstract}
Abstrak
Olahraga sepaktakraw identik dengan gerakan-gerakan akrobatik (contoh: salto, sunback spike, split, dll) yang memiliki tingkat kesulitan tinggi dalam memainkannya. Penelitian ini bertujuan untuk melihat gambaran kejadian cedera ( lokasi cedera, jenis cedera, dan mekanisme terjadinya cedera) yang pernah dialami oleh pemain sepaktakraw di Jawa Barat. Metode yang digunakan dalam penelitian ini yaitu metode deskriptif. Subjek penelitian berjumlah 40 orang atlet putra dan putri yang mengikuti seleksi Pemusatan Latihan Daerah (PELATDA) menjelang babak kualifikasi Pekan Olahraga Nasional (PON) tahun 2020. Instrument penelitian yang digunakan adalah kuesioner dan wawancara terkait jenis cedera yang pernah dialami, tipe cedera dan mekanisme terjadinya cedera. Hasil yang didapatkan menunjukan bahwa lokasi cedera yang paling banyak dialami oleh para pemain sepak takraw terjadi pada ankle (27\%) dengan jenis cedera sprain (47,5\%) dan paling banyak dialami oleh pemain berposisi server dan killer/spiker ketika mereka melakukan gerakan serve (27\%) dan spike (30\%).
\end{abstract}

\footnotetext{
Abstract

Sepaktakraw basically requires acrobatic skills (ex: backflip, sunback spike, split, etc) that has high difficulty in playing it. The aim of this study was to look the incident of injuries (injury body parts, type of injury, and mechanism of injury). This study used descriptive research methods. 40 male and female athletes participated in the pre-season for Indonesian national competition (PON) 2020. The instruments used were questionnaires and interviews regarding the injury body parts, types of injuries and mechanisms injury. The results showed that the most damage experienced by sepaktakraw players occurred at the ankle (27\%) with the type of sprained injury (47.5\%) and was most widely known by serverpositioned players and killer/spiker compilation when they did serve movements (27\%) and spike (30\%).
} 
(C) 2020 Astry Khairunnisa, Pipit Pitriani

Under the license CC BY-SA 4.0

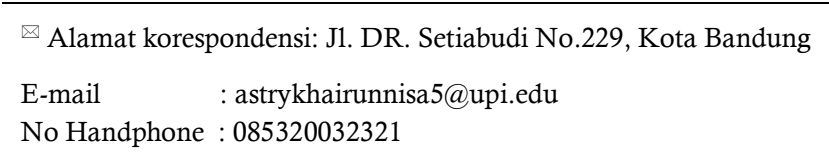

\section{PENDAHULUAN}

Dalam dunia olahraga kejadian cedera ringan maupun parah dalam proses pelatihan dan pertandingan dapat mengakibatkan kehilangan waktu berlatih sehingga dapat memberikan kerugian bagi tim maupun karir pemain tersebut (Alonso et al., 2015). Menurut studi epidemiologis yang dilakukan pada kompetisi olimpiade dan internasional ditemukan bahwa tingkat cedera pada atlet di berbagai cabang olahraga bervariasi, namun pada umumnya $10 \%$ sampai $65 \%$ cedera terjadi pada anggota tubuh bagian bawah (J.M. et al., 2009; Junge et al., 2009). H. Liu et al, (2012) menyebutkan bahwa cedera dalam olahraga yang memiliki karakteristik berlari adalah hamstring strain injury. Cedera tersebut kemungkinan besar terjadi pada saat swing phase dan late stance phase dalam olahraga lari sprint. Sedangkan pada permainan bola basket, sepak bola, dan bola voli lokasi cedera yang paling sering terjadi adalah di bagian knee dengan jenis cedera patellofemoral dysfunction, Osgood-Schlatter disease, dan Sinding-Larsen-Johansson/patella tendinosis (Barber Foss, Myer, \& Hewett, 2014). Perbedaan kejadian cedera tersebut menjadi bukti bahwa cedera yang dialami oleh para atlet berbeda tergantung pada karakteristik olahraganya.

$\begin{array}{rrrr}\text { Salah } & \text { satu cabang } & \text { olahraga yang } \\ \text { memiliki } & \text { karakteristik } & \text { unik } & \text { dalam }\end{array}$ memainkannya yaitu sepaktakraw, yang merupakan kombinasi dari permainan sepak bola, bola voli, baseball, badminton dan sepak raga. (Adam, 2014). Menurut (Hamid, et al, 2015) olahraga sepaktakraw memiliki tingkat kesulitan yang tinggi karena memuat bentuk keterampilan gerak akrobatik. Olahraga sepaktakraw terdiri dari keterampilan dasar dan keterampilan spesialisasi. Keterampilan dasar terdiri dari sepak sila, sepak kura, memaha dan heading, sedangkan keterampilan spesialisasi adalah servis, smash / spike dan block. Disebut sebagai keterampilan dasar karena setiap pemain sepak takraw wajib menguasainya untuk bisa bertahan dan menyerang. Sedangkan keterampilan spesialisasi setiap pemain dapat menguasainya tergantung pada setiap posisi pemain mempunyai tugas gerak masing-masing (Angel, 2010). Pemain sepaktakraw yang berada di tengah disebut tekong yang bertugas untuk melakukan serve, sedangkan pemain yang berada di kanan dan kiri tekong disebut apit kanan dan apit kiri yang bertugas sebagai feeder (pemberi umpan), killer (smasher) atau blocking terhadap serangan lawan (International Sepaktakraw Federation (ISTAF), 2016).

Sepaktakraw yang memuat bentuk keterampilan akrobatik dan memiliki tingkat kesulitan tinggi dalam memainkannya menjadi asumsi dasar bahwa selama proses pelatihan dan pertandingan akan memiliki resiko kejadian cedera yang tinggi. Dalam penelitian ini, yang dibahas adalah lokasi, jenis, dan mekanisme kejadian cedera yang paling sering dialami oleh para pemain sepak takraw. Penelitian tentang cedera ini akan berguna untuk memberikan informasi berkaitan dengan proses dan frekuensi terjadinya cedera kepada pelatih, terapis, dan para ahli di bidang keolahragaan. Penelitian mengenai kejadian cedera pada sepaktakraw khususnya di Indonesia belum pernah dilakukan. Maka dari itu, penelitian ini sangat penting dilakukan oleh peneliti guna memberikan wawasan serta tolak ukur terhadap pelatih untuk melakukan upaya pencegahan cedera selama proses pelatihan dan pertandingan supaya para atlet 
sepaktakraw terutama yang berlaga pada level kompetisi tertinggi di Indonesia yaitu PON dapat meraih prestasi tinggi dengan menghindari resiko cedera yang sering dialami oleh para pemain.

\section{METODE}

Metode yang digunakan dalam penelitian ini ialah metode deskriptif. Subjek penelitian berjumlah 40 orang atlet putra dan putri yang mengikuti seleksi Pemusatan Latihan Daerah (PELATDA) menjelang babak kualifikasi Pekan Olahraga Nasional (PON) tahun 2020. Instrument penelitian yang digunakan adalah kuesioner dan wawancara terkait lokasi cedera, jenis cedera dan mekanisme terjadinya cedera yang pernah dialami.

Pada penelitian ini populasi yang di pilih oleh peneliti adalah seluruh atlet yang mengikuti Pemusatan Latihan Daerah (Pelatda) untuk persiapan menghadapi pertandingan Babak kualifikasi Pekan Olahraga Nasional (BKPON) 2019 sebanyak 40 orang ( laki-laki 20 orang dan perempuan 20 orang). Subjek penelitian yang dipilih oleh peneliti dengan cara purposive sampling yaitu subjek penelitian dipilih sesuai dengan kriteria sebagai berikut :

1. Laki-laki dan perempuan yang berusia sekurang-kurangnya minimal 18 tahun.

2. Telah mengikuti berbagai macam kejuaraan baik tingkat daerah, nasional maupun internasional.

3. Merupakan atlet Jawa Barat yang terpilih mengikuti seleksi pemusatan latihan daerah (Pelatda) untuk persiapan Babak Kualifikasi Pekan Olahraga Nasional (BKPON) 2019.

Seluruh subjek sebelumnya mengisi inform consent yang telah disediakan oleh peneliti yang didalamnya terdapat informasi mengenai tujuan penelitian, alur pengukuran yang dilakukan terhadap subjek, bahaya potensial, dan diberikan hak untuk menolak atau mengundurkan diri sebagai subjek penelitian.

Pada penelitian ini, data diperoleh dari hasil pengisian lembar observasi yang diadopsi dari (Kubo et al, 2016), serta melakukan wawancara langsung untuk memastikan data lembar observasi tersebut terhadap subjek penelitian. Selanjutnya data tersebut disimpan dalam Ms. Excel untuk kemudian di analisis.

Peneliti menganalisis data dengan mengurutkan data tersebut dari yang terbanyak sampai terendah menggunakan Ms. Excel dengan cara data yang diperoleh kemudian dimasukan kedalam tabel sebaran kejadian cedera berdasarkan lokasi cedera, jenis cedera, dan mekanisme cedera dalam bentuk jumlah angka. (misalnya subjek A mengalami cedera ankle sprain ketika melakukan smash maka hitungannya pada lokasi cedera yaitu bagian ankle $; 1$, jenis cedera sprain $; 1$, dan mekanisme cedera ketika smash;1, dst) Setelah mendapatkan sebaran data subjek berdasarkan sub kategori diatas maka selanjutnya menjumlahkan data tersebut dan mengurutkannya dari yang terbanyak sampai terendah dan kemudian tabel tersebut ditampilkan kedalam bentuk diagram pie untuk mempermudah melihat hasilnya.

\section{HASIL DAN PEMBAHASAN \\ Hasil}

Dari subjek penelitian 40 orang yang terdiri dari 20 orang laki-laki dan 20 orang perempuan dan termasuk dalam kriteria yang telah ditentukan hasilnya didapatkan sebagai berikut :

Dari diagram dibawah dapat diketahui bahwa lokasi cedera yang paling sering dialami oleh pemain sepaktakraw adalah ankle (pergelangan kaki) (27\%), selanjutnya paha $(26 \%)$, pergelangan tangan $(18 \%)$ dan lutut $(17 \%)$. 


\section{Diagram 1 Lokasi Cedera}

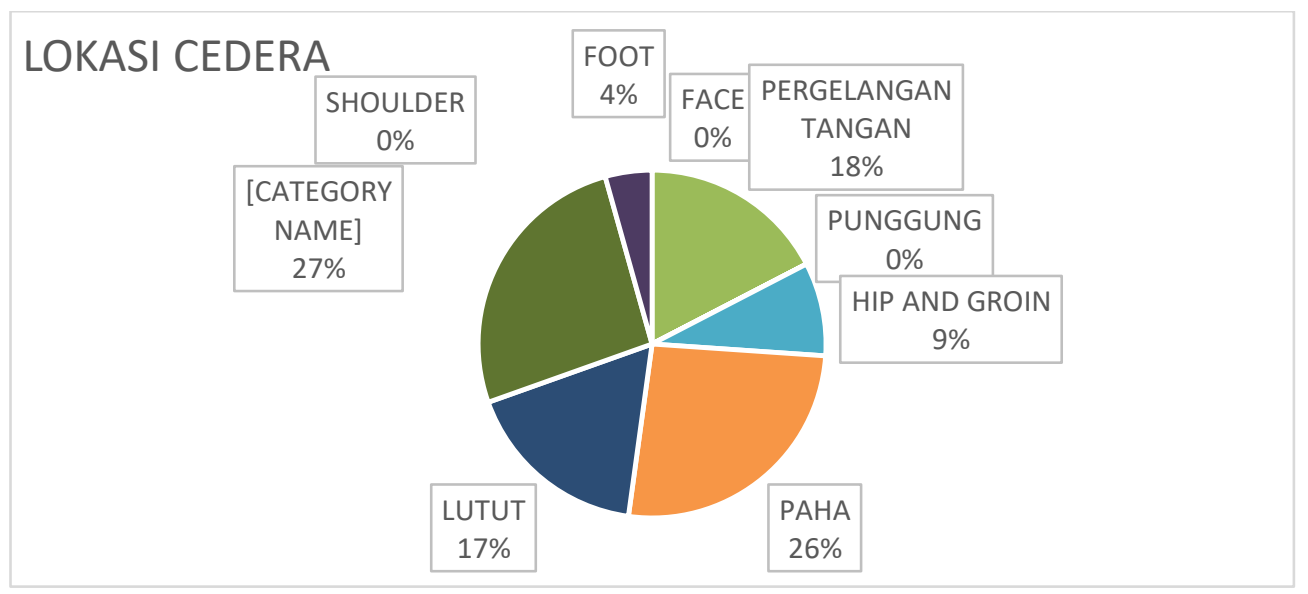

Sementara itu, jenis cedera yang paling sering dialami adalah sprain (50\%) dan strain (25\%). Hal ini sesuai dengan penelitian (Junge et al., 2009) bahwa jenis cedera yang paling umum terjadi di berbagai cabang olahraga adalah sprain dan strain termasuk juga sepaktakraw

Diagram 2 Tipe Cedera

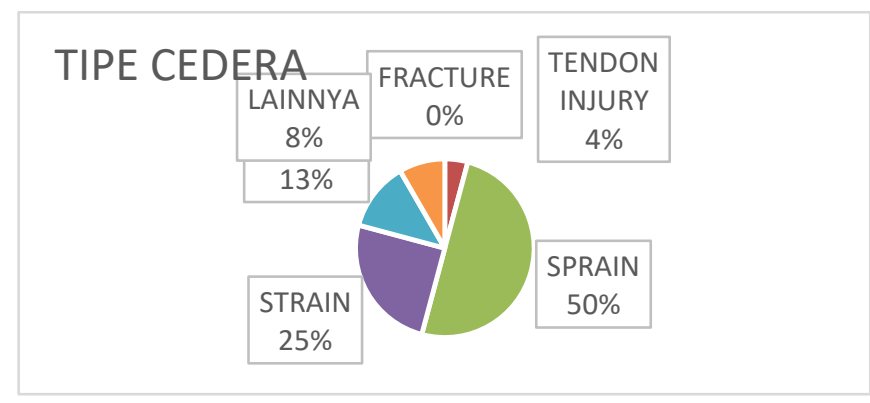

Mekanisme kejadian cedera yang dialami oleh pemain sepaktakraw paling tinggi ketika mereka melakukan smash (50\%), kemudian di ikuti oleh serve (38\%).

Hal ini memperkuat dan menambah temuan (Sujae \& Koh, 2008) yang menyebutkan bahwa gerakan serve dan spike ini memiliki tingkat kesulitan yang tinggi dan ternyata gerakan tersebutpun rentan menyebabkan cedera.

Diagram 3 Mekanisme Cedera

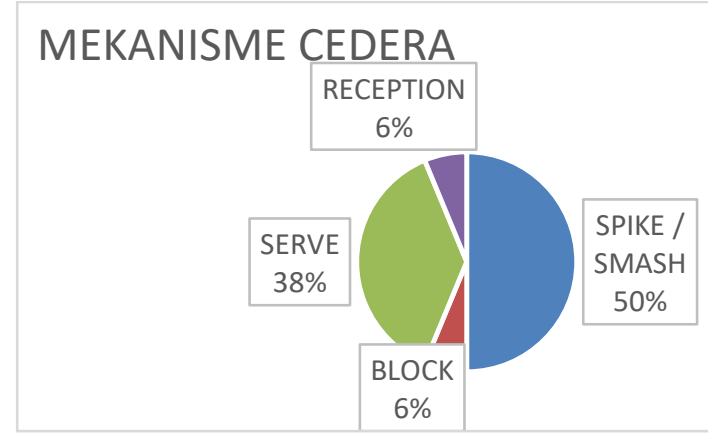




\section{Pembahasan}

Lokasi cedera yang paling sering terjadi yaitu pada ankle. Sendi ankle pada pemain sepak takraw harus fleksible dan kuat untuk menunjang gerakan yang benar dalam melakukan serve maupun smash. Ketika melakukan serve, ankle plantar flexion pada kaki tumpu harus mencapai sudut semaksimal mungkin dan juga harus kuat karena selain untuk menjaga keseimbangan dan beban tubuh, juga harus melakukan gerakan pivot (Sujae \& Koh, 2008). Pada gerakan smash pun sendi ankle ini harus memiliki fleksibilitas dan kekuatan untuk memberikan lecutan saat kaki kontak dengan bola selain itu untuk mendukung keselamatan saat melakukan pendaratan. Dari gerakan smash yang serupa dengan gerakan salto pada olahraga senam, cedera pada ankle pada atlet senam mencapai hampir $70 \%$ dan terjadi ketika fase pendaratan (Xiao, Hao, Li, Wan, \& Shan, 2017).

Hasil penelitian ini tentunya akan berbeda apabila dibandingkan dengan beberapa cabang olahraga lain yang serupa dengan permainan sepaktakraw seperti bola voli, senam dan sepak bola (Adam, 2014). Pada sepak bola, kejadian cedera terjadi paling banyak pada bagian hamstring dengan jenis cedera strain (Engebretsen, Myklebust, Holme, Engebretsen, \& Bahr, 2010; Henderson, Barnes, \& Portas, 2010). Pada bola voli yaitu paling banyak terjadi di knee (Sole, Kavanaugh, \& Stone, 2017). Perbedaan yang dihasilkan ini disebabkan dari beberapa kemungkinan seperti pengertian tentang cedera pada penelitian tersebut, cara pengambilan data, durasi pengambilan data, karakteristik subjek, level kompetisi dan tipe permainan cabang olahraganya itu sendiri.

\section{SIMPULAN}

Sepaktakraw merupakan sebuah olahraga yang memiliki kompleksitas tinggi dalam memainkannya. Banyak gerakangerakan seperti melompat, salto, dan twisting pada lower extremity yang apabila salah dalam melakukannya dapat memicu terjadinya cedera. Lokasi cedera yang paling banyak dialami oleh pemain sepaktakraw di Jawa Barat ialah pada bagian ankle, paha (hamstring), dan knee. Jenis cedera yang sering terjadi adalah sprain dan strain saat mereka melakukan gerakan servis dan smash. Hal tersebut kemungkinan besar karena ketika melakukan gerakan smash dan servis bagian ankle ini lebih dominan digunakan karena menjadi poros kedua gerakan tersebut.

Fleksibilitas sendi ankle pada pemain sepak takraw memerlukan perhatian khusus karena pada saat gerakan servis, ankle plantar flaxion harus mencapai sudut semaksimal mungkin baik untuk kaki tumpu yang dibarengi dengan gerakan pivot, maupun kaki lainnya yang kontak dengan bola untuk melakukan lecutan. Sendi ankle ini pun menjadi sendi dominan juga untuk melakukan gerakan smash/spike ketika mereka melakukan lompatan, lecutan kaki yang kontak dengan bola, dan saat pendaratan. Saat pendaratan ketika smash, sendi ankle ini memerlukan kestabilan dan juga kekuatan untuk menopang berat tubuh, karena ketika sendi ankle tidak stabil dan kurang kuat maka resiko cedera akan meningkat akibat kesalahan gerak.

Saran khusus untuk pelatih dan atlet supaya lebih aware terhadap kejadian cedera yang dialami terutama pada bagian ankle. Disarankan juga untuk memberi porsi latihan lain terutama untuk menunjang fleksibilitas dan kekuatan sendi ankle pada setiap atlet. Bagi atlet yang pernah mengalami cedera pada sendi ankle, harus melakukan pemanasan semaksimal mungkin dan mengikuti program latihan yang telah di instruksikan pelatih sebagai upaya pencegahan terjadinya cedera berulang. Selain itu, pengobatan cedera harus dilakukan sampai tuntas sesuai yang di instruksikan oleh dokter atau therapist.

\section{SARAN}

Penelitian mengenai kejadian cedera pada pemain sepak takraw masih sangat jarang 
dilakukan sehingga informasi mengenai hal tersebut masih sangat minim. Hasil dari penelitian ini diharapkan dapat menambah wawasan dan pengetahuan terkait lokasi cedera yang paling banyak dialami oleh pemain sepak takraw, jenis cedera yang dialami serta mekanisme kejadian cedera tersebut sehingga dapat menjadi tolak ukur untuk upaya pencegahan serta dijadikan sebagai referensi pihak-pihak yang terlibat. Penelitian ini memiliki beberapa keterbatasan diantaranya bahwa data yang diperoleh yaitu dari lembar observasi serta wawancara bukan dari basis data lembaga yang berwenang, maka disarankan untuk selanjutnya agar melakukan penelitian dengan analisis yang lebih dalam misalnya analisis biomekanik, biomotorik, dan atau berbasis teknologi kinovea atau dartfish, dan lain-lain. Penelitian ini juga tidak membahas mengenai upaya pencegahan kejadian cedera dan data yang didapatkan terbatas kepada para pemain sepak takraw di Jawa Barat saja, sehingga diperlukan penelitian lebih lanjut di daerah lain dengan karakteristik subjek yang berbeda.

\section{UCAPAN TERIMA KASIH}

Dalam pembuatan artikel ini banyak pihak yang membantu sehingga penulis dapat menyelesaikannya, untuk itu penulis mengucapkan terimakasih kepada: Bapak Sucipto selaku Ketua Pengurus Daerah (PENGDA) PSTI Jawa Barat yang telah memberikan izin kepada penulis untuk melakukan penelitian ini, dan kepada Ibu Pipit Pitriani sebagai dosen pembimbing, atas bimbingan, saran, dan pengarahannya sehingga penulisan artikel ini dapat diselesaikan. Demikian juga untuk kedua reviewers yang telah menyampaikan sumbangan pemikirannya dalam melakukan pembenahan dan penyempurnaan artikel ini. Adapun kesalahan yang penulis lakukan sepenuhnya kesalahan dari penulis.

\section{DAFTAR PUSTAKA}

Adam, N. (2014). Experimental Analysis of Mechanical Properties of Selected Takraw Balls in Malaysia, 1-21.

Alonso, J. M., Jacobsson, J., Timpka, T., Ronsen, O., Kajenienne, A., Dahlström, Ö., ... Edouard, P. (2015). Preparticipation injury complaint is a risk factor for injury: A prospective study of the Moscow 2013 IAAF Championships. British Journal of Sports Medicine, 49(17), 1118-1124. https://doi.org/10.1136/bjsports-2014094359

Angel, R. (2010). Dasar-Dasar Sepak Takraw (First). Canada: Pakan Raya, Bandung.

Barber Foss, K. D., Myer, G. D., \& Hewett, T. E. (2014). Epidemiology of basketball, soccer, and volleyball injuries in middleschool female athletes. Physician and Sportsmedicine, 42(2), 146-153. https://doi.org/10.3810/psm.2014.05.206 6

Engebretsen, A. H., Myklebust, G., Holme, I., Engebretsen, L., \& Bahr, R. (2010). Intrinsic Risk Factors for Hamstring Injuries Among Male Soccer Players. The American Journal of Sports Medicine, 38(6), 1147-1153. https://doi.org/10.1177/03635465093583 81

Hamid, N. A., Babjan, A. M., Abdullah, M. N., \& Ismail, S. (2015). Anthropometric and physiological profiles of sepak takraw players. British Journal of Sports Medicine, 39(11), 825-829; https://doi.org/10.1136/bjsm.2004.01691 5

Henderson, G., Barnes, C. A., \& Portas, M. D. (2010). Factors associated with increased 
propensity for hamstring injury in English Premier League soccer players. Journal of Science and Medicine in Sport, 13(4), 397-402. https://doi.org/10.1016/j.jsams.2009.08.0 03

International Sepaktakraw Federation (ISTAF). (2016). Law Of The Game.

Junge, A., Engebretsen, L., Mountjoy, M. L., Alonso, J. M., Renström, P. A. F. H., Aubry, M. J., \& Dvorak, J. (2009). Sports injuries during the Summer Olympic Games 2008. American Journal of Sports Medicine, 37(11), 2165-2172. https://doi.org/10.1177/03635465093393 57

Kubo, Y., Nakazato, K., Koyama, K., Tahara, Y., Funaki, A., \& Hiranuma, K. (2016). The Relation between Hamstring Strain Injury and Physical Characteristics of Japanese Collegiate Sepak Takraw Players. International Journal of Sports Medicine, 37(12), 986-991. https://doi.org/10.1055/s-0042-114700

Liu, H., Garrett, W. E., Moorman, C. T., \& $\mathrm{Yu}$, B. (2012). Injury rate, mechanism, and risk factors of hamstring strain injuries in sports: A review of the literature. Journal of Sport and Health

Science, $\quad 1(2), \quad 92-101$. https://doi.org/10.1016/j.jshs.2012.07.00 3

Sole, C., Kavanaugh, A., \& Stone, M. (2017). Injuries in Collegiate Women's Volleyball: A Four-Year Retrospective Analysis. Sports, 5(2), 26. https://doi.org/10.3390/sports5020026

Sujae, I. H., \& Koh, M. (2008a). Technique analysis of the kuda and sila serves in sepaktakraw. Sports Biomechanics. https://doi.org/10.1080/14763140701687 552

Sujae, I. H., \& Koh, M. (2008b). Technique analysis of the kuda and sila serves in sepaktakraw. Sports Biomechanics, 7(1), 72-87.

https://doi.org/10.1080/14763140701687 552

Xiao, X., Hao, W., Li, X., Wan, B., \& Shan, G. (2017). The influence of landing mat composition on ankle injury risk during a gymnastic landing: A biomechanical quantification. Acta of Bioengineering and Biomechanics, 19(1), 105-113. https://doi.org/10.5277/ABB-005832016-02 